\title{
Pengaruh jenis dan rasio substitusi tepung beras hitam terhadap karakteristik fisikokimia rempeyek
}

\author{
The effect of different types and substitution ratios of black rice flour on \\ physicochemical properties of rempeyek \\ Nuri Arum Anugrahati ${ }^{1)^{*}}$, Priscilla Aurielle ${ }^{1)}$ \\ ${ }^{1}$ Program Studi Teknologi Pangan, Fakultas Sains dan Teknologi, \\ Universitas Pelita Harapan \\ *Email korespondensi : nuri.anugrahati@uph.edu \\ Informasi Artikel: \\ Dikirim: 12/01/2021; disetujui: 15/07/2021; diterbitkan: 30/09/2021
}

\begin{abstract}
Black rice is one type of rice cultivated in Indonesia which has a hard and dry texture, so it is rarely consumed. Black rice can be divided into organic and non-organic types. One of the processing methods to utilize black rice is coverting it into flour for substitute white rice in rempeyek formula. The purposes of this research were to determine the physicochemical characteristics of organic and non-organic black rice flour and to determine the effect of different types and ratios substitution of black rice flour on physicochemical characteristics of rempeyek. White rice and organic and non-organic black rice flour ratios for rempeyek formula were 100: 0; 80:20; 60:40; 40:60; and 20:80. Parameter analyses of this research were yield, moisture content, water absorption content, dietary fiber content, and resistant starch content of organic and non-organic black rice flour; hardness and fracturability of rempeyek. The result showed

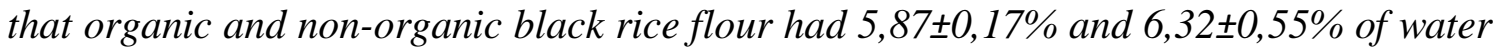
content, $118,07 \pm 3,07 \%$ and $113,20 \pm 5,48 \%$ of water absorption content, $8,50 \pm 0,15 \%$ and $7,06 \pm 0,02 \%$ of dietary fiber, $3,84 \pm 0,01 \%$ and $1,86 \pm 0,01 \%$ of resistant starch content. The higher ratio of organic black rice substitution on the rempeyek formula, the higher hardness and fracturability of rempeyek. The best rempeyek formula was 20 white rice flour:80 organic black rice flour which gave hardness 730,28 $\pm 11,74$ gf, fracturability

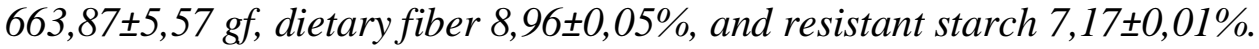

Keywords: black rice, dietary fiber, fracturability, organic, rempeyek, resistant starch

\begin{abstract}
ABSTRAK
Beras hitam merupakan salah satu jenis beras yang dibudidayakan di Indonesia yang memiliki tekstur kering dan keras sehingga jarang dikonsumsi. Beras hitam dapat dibedakan menjadi organik dan non-organik. Salah satu cara pemanfaatan beras hitam adalah dengan membuatnya menjadi tepung dan menjadikannya sebagai pengganti beras putih dalam formula rempeyek. Tujuan penelitian adalah untuk mengetahui karakteristik fisikokimia tepung beras hitam organik dan non-organik dan mengetahui pengaruh perbedaan jenis dan rasio substitusi tepung beras hitam terhadap sifat fisikokimia rempeyek. Rasio substitusi tepung putih dan tepung beras hitam organik dan non-organik pada formula rempeyek sebesar 100: 0; 80:20; 60:40; 40:60; dan 20:80. Parameter yang dianalisis meliputi rendemen, kadar air, daya serap air, kadar serat pangan, dan kadar pati resisten pada beras hitam organik dan non-organik, kekerasan dan daya patah pada semua
\end{abstract}


formula rempeyek dan rempeyek komersial. Hasil penelitian menunjukkan tepung beras hitam organik dan non organik memiliki kadar air 5,87 $\pm 0,17 \%$ dan $6,32 \pm 0,55 \%$, daya serap air $118,07 \pm 3,07 \%$ dan $113,20 \pm 5,48 \%$, kadar serat pangan $8,50 \pm 0,15 \%$ dan 7,06 $\pm 0,02 \%$, serta kadar pati resisten $3,84 \pm 0,01 \%$ dan $1,86 \pm 0,01 \%$. Semakin tinggi rasio substitusi beras hitam organik, maka semakin meningkat kekerasan dan daya patah rempeyek. Formula rempeyek terbaik dihasilkan pada rasio substitusi tepung beras putih dan tepung beras hitam organik (20:80) dengan kekerasan 730,28 \pm 11,74 gf, daya patah $663,87 \pm 5,57$ gf, kadar serat pangan 8,96 $\pm 0,05 \%$, dan kadar pati resisten 7,17 $\pm 0,01 \%$.

Kata kunci: beras hitam, daya patah, dietary fiber, organik, pati resisten, rempeyek

\section{PENDAHULUAN}

Beras putih merupakan salah satu hasil pertanian terbesar yang menjadi makan pokok di Indonesia. Beras putih memiliki kandungan karbohidrat yang tinggi yaitu 77$78 \mathrm{~g} / 100 \mathrm{~g}$ (Saleh et al., 2019) dan mengalami penyosohan sehingga kadar seratnya rendah yaitu sebesar $2,4 \mathrm{~g} / 100 \mathrm{~g}$ (Kristamtini et al., 2014).

Beras hitam merupakan salah satu beras yang dibudidayakan di Indonesia. Kadar serat beras hitam dilaporkan lebih tinggi daripada beras putih. Beras hitam memiliki kadar karbohidrat sebesar 76,9 g/100 g (Kristamtini et al., 2014) dan kadar serat sebesar 20,1 g/100 g (Nurhidajah et al., 2018). Beras hitam berdasarkan sistem penanamannya dapat dibagi menjadi beras organik dan non-organik. Beras organik adalah beras yang ditanam dengan pupuk alami (tanpa bahan kimia) yang bersahabat dengan lingkungan (Sulistyana et al., 2014). Beras yang ditanam dengan sistem organik memiliki kandungan gizi yang lebih tinggi dibandingkan beras non-organik. Beras hitam organik juga biasanya dijual di tempat khusus dan memiliki harga yang relatif lebih mahal dibandingkan beras lainnya.

Beras hitam masih jarang dikonsumsi karena tekstur yang keras dan membutuhkan waktu masak yang lebih lama (Nurhidajah et al., 2018). Beras hitam umumnya diolah menjadi tepung terlebih dahulu sehingga dapat dimanfaatkan menjadi berbagai macam produk pangan seperti bakpao, muffin, flakes, dan kue tradisional.

Rempeyek merupakan salah satu makanan tradisional yang berasal dari Jawa Tengah. Rempeyek biasa dijadikan makanan pendamping seperti pada pecel ataupun cemilan. Rempeyek umumnya dibuat dari campuran tepung beras putih dan tapioka serta ditambah kacang, ebi, atau teri di atasnya. Rempeyek sebagai produk gorengan memiliki ciri khas tekstur yang renyah. Berdasarkan penelitian Paramida et al. (2013), rempeyek dengan kerenyahan terbaik dihasilkan pada rasio tepung beras dan tapioka 62,5:37,5.

Indonesia adalah negara dengan kebiasaan mengemil tertinggi di Asia Pasifik (Kahono et al., 2018). Pembuatan rempeyek dengan substitusi tepung beras hitam dapat dilakukan untuk menghasilkan cemilan yang nikmat dan lebih sehat serta meningkatkan penggunaan beras hitam yang masih jarang dikonsumsi. Oleh karena itu penelitian bertujuan untuk mengetahui karakteristik fisikokimia tepung beras hitam organik dan non-organik dan mengetahui pengaruh jenis dan rasio substitusi tepung beras hitam organik dan non-organik terhadap sifat fisikokimia rempeyek.

\section{METODE}

\section{Bahan}

Bahan-bahan dalam penelitian meliputi tepung beras putih (Rose Brand), beras hitam organik (RHT) dari Yogyakarta, beras hitam non-organik (FS) dari Jawa Tengah, tepung tapioka, ketumbar bubuk, bawang putih bubuk, garam, gula pasir, irisan daun jeruk, santan kelapa siap pakai, air, minyak goreng, akuades, heksana, $\mathrm{K}_{2} \mathrm{SO}_{4}$, selenium, $\mathrm{H}_{2} \mathrm{SO}_{4}$, $\mathrm{H}_{2} \mathrm{O}_{2}, \mathrm{NaOH}, \mathrm{H}_{3} \mathrm{BO}_{4}, \quad \mathrm{HCl} 0,2 \mathrm{~N}$, mix indicator, etanol, aseton, buffer fosfat $\mathrm{pH} 7$, enzim $\alpha$-amilase, enzim pepsin, enzim $\beta$ - 
amilase (Sigma-Aldrich), $\mathrm{HCl} 1 \mathrm{~N}, \mathrm{NaOH} 1$ $\mathrm{N}, \mathrm{HCl} 25 \%, \mathrm{NaOH} 45 \%$ (Merck).

Alat

Alat yang digunakan dalam penelitian adalah timbangan analitik, timbangan dapur digital, disc mill, dry blender, ayakan 80 mesh, cabinet dyer, tray cabinet $68 \times 52 \mathrm{~cm}$, oven (Memmert Une 200-800), desikator, cetakan rempeyek, cawan penguapan, kondensor, cawan pengabuan, centrifuge (Hermle Labortechnik GmbH Z 206 A), tabung centrifuge, gelas beaker, gelas ukur, heater, labu lemak, labu takar, Erlenmeyer, labu evaporator, rotary evaporator (Heidolph Hei-VAP Advantage), kondensor, tanur (Barnstead Thermolyne 62700), vortex, burner, Kjeldhal flask, Kjeldahl (Buchi Destilation Unit K-355), alat digestion (Buchi Scrubber K-415), titrator (Schott TitroLine), Texture Analyzer (Stable Micro System TA.XT Plus).

\section{Metode}

Penelitian dilakukan dengan metode eksperimental. Penelitian dibagi menjadi 2 tahap, yaitu tahap I dan II.

\section{Penelitian tahap I}

Pembuatan tepung beras hitam organik dan non-organik dilakukan mengacu pada metode Maureen et al. (2016). Pembuatan tepung diawali dengan proses perendaman beras hitam dengan air (1:3) selama 2 jam. Beras hitam yang sudah direndam lalu dipisahkan dari air rendaman, kemudian dihancurkan dengan menggunakan $d r y$ blender, dan dikeringkan di dalam cabinet dryer pada suhu $50-60^{\circ} \mathrm{C}$ selama 4 jam. Setelah kering, beras hitam selanjutnya dihaluskan dengan menggunakan disc mill dan diayak dengan ayakan berukuran 80 mesh.

\section{Penelitian tahap II}

Pembuatan rempeyek dilakukan dengan mencampurkan semua tepung (tepung beras putih, hitam, dan tapioka) dan bumbu hingga tercampur homogen. Setelah tercampur, santan dan air ditambahkan hingga membentuk adonan yang homogen. Adonan homogen kemudian digoreng dengan cara menuangkan adonan ke cetakan rempeyek yang sebelumnya sudah direndam (sekitar 2 menit) dalam wajan berisi minyak panas $\left(160^{\circ} \mathrm{C}\right)$. Formula rempeyek mengacu pada Nadhifah et al. (2016) dan Paramida et al. (2013) dengan modifikasi seperti pada Tabel 1.

Tabel 1. Formula rempeyek

\begin{tabular}{ll}
\hline \multicolumn{1}{c}{ Bahan } & \multicolumn{1}{c}{ Jumlah (\%) } \\
\hline Tepung beras putih & $30 ; 24 ; 18 ; 12 ; 6$ \\
Tepung beras hitam* & $0 ; 6 ; 12 ; 24 ; 24$ \\
Tepung tapioka & 9 \\
Ketumbar bubuk & 0,75 \\
Garam & 1,5 \\
Gula & 0,75 \\
Bawang putih bubuk & 0,75 \\
Daun jeruk & 1 \\
Santan & 5 \\
Air & 51,25 \\
\hline
\end{tabular}

*Organik, non-organik

\section{Rancangan percobaan}

Rancangan percobaan tahap I adalah Rancangan Acak Lengkap (RAL) dengan 1 faktor yaitu jenis beras hitam organik dan non-organik. Rancangan percobaan pada tahap II adalah RAL dengan dua faktor dan 3 ulangan. Rasio tepung beras putih:tepung beras hitam (A) yaitu 100:0; 80:20; 60:40; 40:60; 20:80 dan jenis tepung beras hitam (B) yaitu organik dan non-organik. Data penelitian diolah dengan ANOVA oneway dan uji lanjutan Duncan menggunakan SPSS versi 23.

\section{Analisis data}

Analisis yang dilakukan pada tahap I meliputi rendemen (Ntau et al., 2017), daya serap air (Rauf \& Sarbini, 2015), kadar air, kadar serat pangan, dan kadar pati resisten (AOAC, 2012). Analisis yang dilakukan pada tahap II meliputi tekstur kekerasan dan daya patah (Engelen, 2018), kadar air, kadar protein, kadar lemak, kadar serat pangan, dan kadar pati resisten (AOAC, 2012).

\section{HASIL DAN PEMBAHASAN}

\section{Rendemen tepung beras hitam}

Hasil analisis statistik menunjukkan bahwa jenis beras hitam yang berbeda tidak memengaruhi rendemen yang dihasilkan 
( $>0,05)$. Beras hitam organik memiliki rendemen sebesar $92,63 \pm 0,06 \%$ dan beras hitam non-organik sebesar 92,55 $\pm 0,57 \%$. Hasil rendemen beras hitam organik yang tidak berbeda nyata secara statistik dengan beras hitam non-organik dapat disebabkan berat bahan awal dan kondisi pengeringan relatif sama antara kedua jenis beras. Beberapa faktor yang dilaporkan dapat memengaruhi rendemen tepung lain seperti tapioka diantaranya adalah berat bahan awal, ukuran partikel, suhu dan lama pengeringan (Mustafa, 2015).

\section{Kadar air tepung beras hitam}

Hasil analisis statistik menunjukkan tidak adanya perbedaan kadar air untuk kedua jenis tepung beras hitam ( $p>0,05)$. Kadar air tepung beras hitam organik ialah sebesar 5,87 $\pm 0,17 \%$ dan non-organik sebesar $6,33 \pm 0,55 \%$. Kadar air dapat menentukan umur simpan tepung. Semakin rendah kadar air tepung, maka semakin lama umur simpan tepungnya. Tepung yang memiliki kadar air di bawah $10 \%$ memiliki umur simpan yang lebih lama, yaitu lebih dari 1 tahun (Aini et al., 2016).

\section{Daya serap air tepung beras hitam}

Analisis statistik daya serap air menunjukkan tidak adanya perbedaan untuk kedua jenis tepung beras $(\mathrm{p}>0,05)$. Daya serap air untuk tepung beras hitam organik ialah sebesar 118,07 $\pm 3,07 \%$ dan non-organik sebesar $113,20 \pm 5,48 \%$. Daya serap air dapat berhubungan dengan kadar air tepungnya. Semakin rendah kadar airnya, maka daya serap airnya semakin tinggi. Selain itu daya serap air dapat berhubungan dengan kadar amilosa tepungnya. Semakin tinggi kadar amilosa, maka kemampuan pati dalam menyerap air dan mengembang semakin besar (Sari et al., 2020).

\section{Kadar serat pangan tepung beras hitam}

Hasil analisis statistik menunjukkan adanya pengaruh jenis beras hitam terhadap kadar serat pangan tepung beras yang dihasilkan $(\mathrm{p}<0,05)$. Kadar serat pangan tepung beras hitam organik dan non-organik dapat dilihat pada Gambar 1.

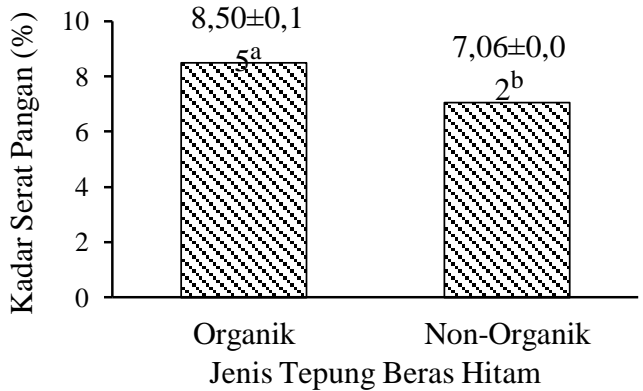

Keterangan: Notasi huruf berbeda menunjukkan adanya perbedaan yang signifikan $(\mathrm{p}<0,05)$

Gambar 1. Kadar serat pangan tepung beras hitam organik dan non-organik

Gambar 1 menunjukkan tepung beras hitam organik memiliki kadar serat pangan yang lebih tinggi dibandingkan tepung beras hitam non-organik. Hasil kadar serat pangan yang lebih tinggi pada tepung beras hitam organik dapat dipengaruhi oleh kondisi penanamannya. Menurut (Hernawan dan Meylani, 2016), beras hitam organik memiliki kadar serat pangan yang lebih tinggi dibandingkan beras hitam non-organik dan paling tinggi bila dibandingkan dengan beras putih dan merah. Kondisi tanah dapat memengaruhi kadar serat pangan. Kondisi tanah menentukan komposisi gizi dari produk yang ditanam (Kopittke et al., 2019). Pangan organik ditanam tanpa pemberian pestisida dan bahan kimia lainnya sehingga gizi yang terkandung dalam pangan organik dapat lebih tinggi (Vigar et al., 2020).

\section{Kadar pati resisten tepung beras hitam}

Hasil analisis statistik menunjukkan adanya pengaruh jenis beras hitam terhadap kadar pati resisten tepung beras yang dihasilkan $(\mathrm{p}<0,05)$. Kadar pati resisten tepung beras hitam organik dan non-organik dapat dilihat pada Gambar 2. 


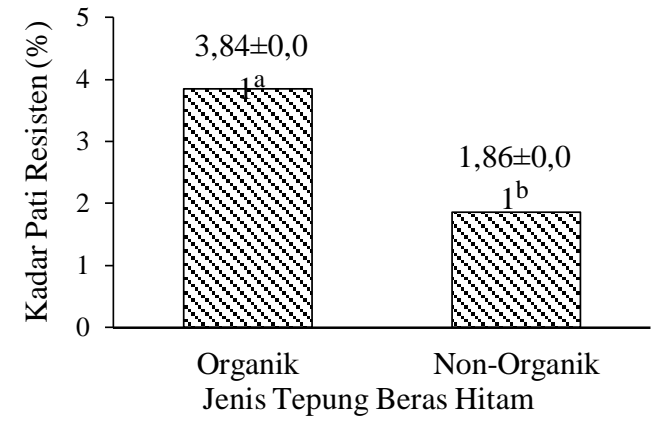

Keterangan: Notasi huruf berbeda menunjukkan adanya perbedaan yang signifikan $(\mathrm{p}<0,05)$

Gambar 2. Kadar pati resisten tepung beras hitam organik dan non-organik

Gambar 2 menunjukkan tepung beras hitam organik memiliki kadar pati resisten yang lebih tinggi dibandingkan beras hitam non-organik. Sistem penanaman organik dapat menyebabkan terbentuknya amiloplas yang besar dengan banyak granula pati di dalamnya dan dapat meningkatkan kandungan amilosa seiring peningkatan kandungan nitrogen dan mineral (Fe, $\mathrm{Mn}$, dan Zn) pada tanah (Kakar et al., 2019). Amilosa diketahui tersusun atas rantai linear dan rantai tersebut mudah membentuk struktur yang kompak sehingga akan sulit untuk dicerna oleh tubuh (Rozali, 2018). Menurut (Anugrahati et al., 2015), beras dengan kandungan amilosa yang lebih tinggi memiliki kandungan pati resisten yang tinggi.

\section{Tekstur rempeyek}

Parameter tekstur rempeyek yang diuji meliputi kekerasan (hardness) dan daya patah (fracturability). Hasil analisis statistik menunjukkan bahwa perbedaan jenis tepung beras dan rasio tepung beras hitam memengaruhi kekerasan rempeyek yang dihasilkan secara signifikan $(\mathrm{p}<0,05)$. Kekerasan rempeyek dengan perbedaan jenis dan rasio substitusi tepung beras hitam dapat dilihat pada Gambar 3.

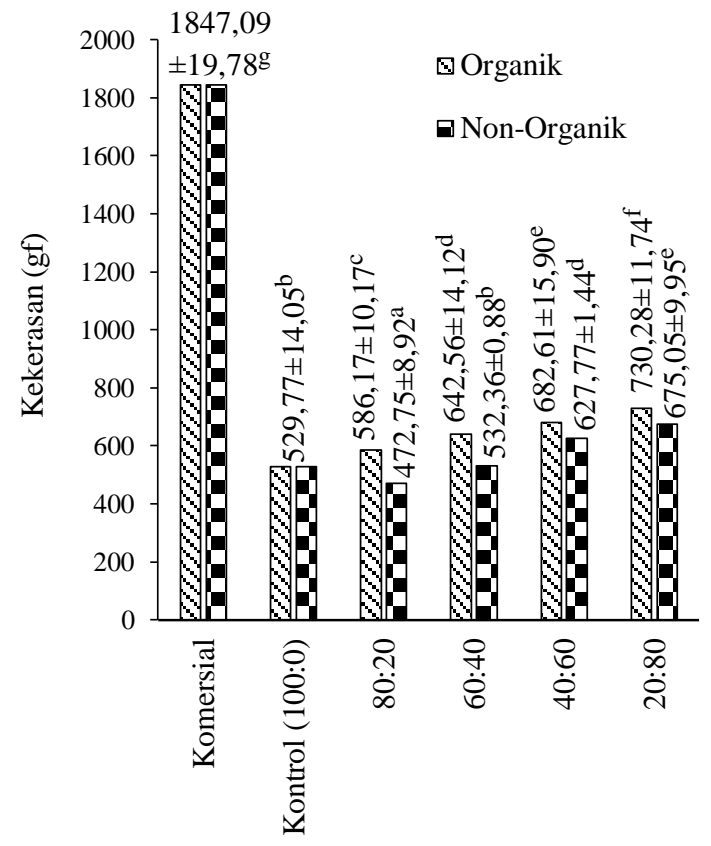

Rasio Tepung Beras Putih:Hitam

Keterangan: Notasi huruf berbeda menunjukkan adanya perbedaan yang signifikan $(\mathrm{p}<0,05)$

Gambar 3. Kekerasan rempeyek dengan perbedaan jenis dan rasio substitusi tepung beras hitam

Kekerasan rempeyek pada Gambar 3 menunjukkan semakin tinggi tepung beras yang disubstitusi maka tekstur rempeyek yang dihasilkan juga semakin tinggi. Nilai kekerasan rempeyek dengan rasio substitusi tepung beras putih:tepung beras hitam organik 20:80 adalah setengah kali lebih kecil dari nilai kekerasan rempeyek komersial, sehingga dapat dinyatakan rempeyek substitusi tepung beras hitam organik tersebut tergolong renyah. Produk dikatakan renyah apabila memiliki tekstur yang tidak keras (Sugiyono et al., 2013). Beberapa faktor yang dapat memengaruhi kekerasan rempeyek yang dihasilkan, seperti kadar air yang tinggi (Engelen, 2018), kandungan serat pangan tinggi, kandungan amilosa beras hitam yang tinggi sehingga membentuk adonan yang kental, dan perbedaan komposisi serta formula rempeyek. Kandungan amilosa beras hitam yang tinggi dilaporkan dapat menurunkan porositas produk pangan (Jagat et al., 2017).

Hasil uji statistik menunjukkan bahwa jenis tepung beras dan rasio tepung beras hitam memengaruhi daya patah rempeyek 
secara signifikan $(\mathrm{p}<0,05)$. Daya patah rempeyek dengan perbedaan jenis dan rasio substitusi tepung beras hitam ditunjukkan pada Gambar 4.

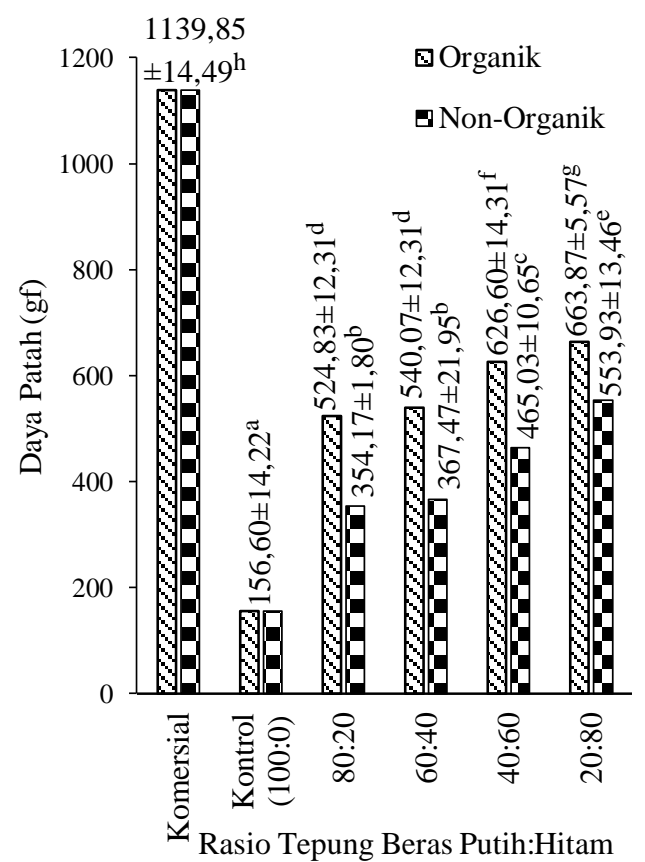

Keterangan: Notasi huruf berbeda menunjukkan adanya perbedaan yang signifikan $(\mathrm{p}<0,05)$

Gambar 4. Daya patah rempeyek dengan perbedaan jenis dan rasio substitusi tepung beras hitam

Pada Gambar 4 dapat dilihat bahwa semakin tinggi substitusi tepung beras hitam pada formula rempeyek, maka daya patah rempeyek semakin tinggi. Suatu produk dapat dikatakan renyah apabila mudah patah (Nadhiroh dam Susanto, 2017). Produk yang renyah akan patah saat pertama kali digigit. Komposisi dan ketebalan dapat memengaruhi daya patah rempeyek. Kandungan amilosa yang tinggi dapat menyebabkan adonan yang terbentuk kental sehingga rempeyek yang dihasilkan semakin tebal. Daya patah yang tinggi juga dapat dipengaruhi oleh proses penyimpanan (Nadhifah et al., 2016).

\section{Komposisi kimia rempeyek formula terbaik}

Rempeyek dengan formula terbaik ditentukan berdasarkan kerenyahan yang dilihat dari hasil kekerasan dan daya patah yang paling mendekati rempeyek komersial. Formula rempeyek terbaik ditunjukkan oleh rasio substitusi tepung beras putih:tepung beras hitam (20:80). Komposisi kimia rempeyek formula terbaik dapat dilihat pada Tabel 2.

Tabel 2. Komposisi kimia rempeyek formula terbaik

\begin{tabular}{lc}
\hline \multicolumn{1}{c}{ Parameter } & Hasil $(\% \mathbf{b} / \mathbf{b})$ \\
\hline Kadar air & $2,91 \pm 0,12$ \\
Kadar protein & $6,57 \pm 0,12$ \\
Kadar lemak & $19,88 \pm 0,76$ \\
Kadar abu & $3,84 \pm 0,18$ \\
Kadar karbohidrat & $66,80 \pm 0,64$ \\
Kadar serat pangan & $8,96 \pm 0,05$ \\
Kadar pati resisten & $7,17 \pm 0,01$ \\
\hline
\end{tabular}

\section{Perbandingan karakteristik fisikokimia rempeyek formula terbaik dengan rempeyek komersial}

Hasil uji statistik menunjukkan bahwa rempeyek komersial, kontrol, dan formulasi terbaik memiliki kadar air yang berbeda $(\mathrm{p}<0,05)$. Kadar air rempeyek komersial, kontrol, dan formula terbaik dapat dilihat pada Gambar 5.

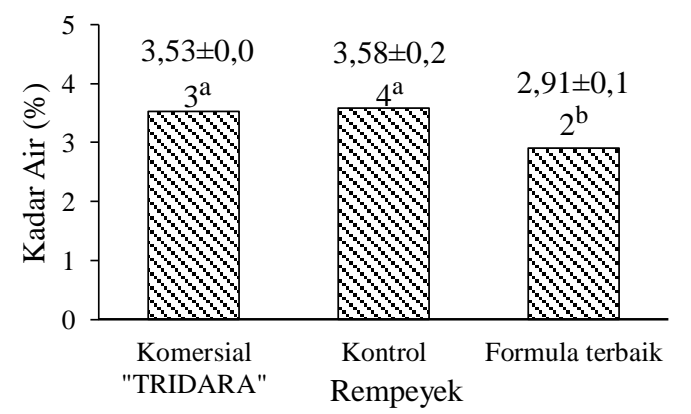

Keterangan: Notasi huruf berbeda menunjukkan adanya perbedaan yang signifikan $(\mathrm{p}<0,05)$

Gambar 5. Kadar air rempeyek komersial, kontrol, dan formula terbaik

Gambar 5 menunjukkan rempeyek formula terbaik yang dibuat dengan penambahan tepung beras hitam memiliki kadar air yang lebih rendah dibandingkan rempeyek komersial dan kontrol. Hal tersebut dapat dipengaruhi oleh kadar air tepung beras hitam yang digunakan lebih rendah yaitu sebesar 5,87\% dibandingkan kadar air tepung beras putih yaitu sekitar 12,83\% (Wulandari et al., 2016). Suhu minyak dan luas permukaan rempeyek juga dapat memengaruhi kadar air produk (Nadhiroh dan Susanto, 2017). 


\section{Kadar protein rempeyek}

Hasil analisis statistik menunjukkan adanya perbedaan signifikan untuk kadar protein rempeyek komersial, kontrol, dan formulasi terbaik $(\mathrm{p}<0,05)$. Kadar protein rempeyek komersial, kontrol, dan formula terbaik ditunjukkan pada Gambar 6 .

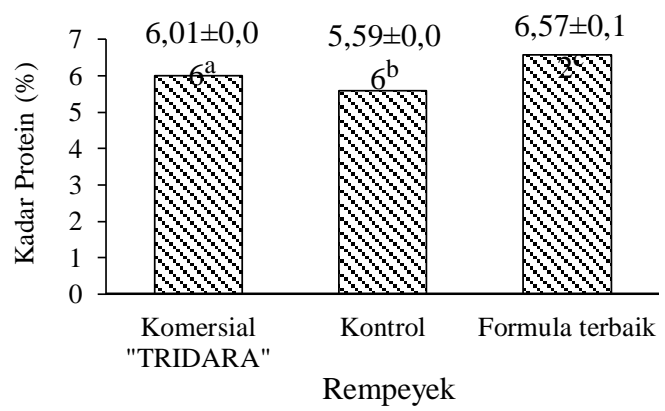

Keterangan: Notasi huruf berbeda menunjukkan adanya perbedaan yang signifikan $(\mathrm{p}<0,05)$

Gambar 6. Kadar protein rempeyek komersial, kontrol, dan formula terbaik

Rempeyek formula terbaik hasil substitusi tepung beras hitam pada Gambar 6 menunjukkan kadar protein yang paling tinggi daripada rempeyek komersial dan kontrol. Kadar protein tertinggi pada rempeyek formula terbaik dapat dipengaruhi oleh kadar protein. Tepung beras hitam memiliki kandungan protein $9,97 \%$ (Hidayat et al., 2019), sedangkan kadar protein tepung beras putih hanya sebesar 7,59\% (Purnama et al., 2019). Rempeyek komersial memiliki kadar protein yang lebih tinggi dari kontrol karena adanya ikan teri yang ditambahkan ke dalam formula. Perbedaan komposisi, dan suhu penggorengan juga dapat memengaruhi kadar protein. Semakin tinggi suhu penggorengan, semakin besar kemungkinan protein mengalami denaturasi (Sundari et al., 2015).

\section{Kadar lemak rempeyek}

Hasil analisis statistik menunjukkan adanya perbedaan kadar lemak yang signifikan untuk rempeyek komersial, kontrol, dan formula terbaik $(\mathrm{p}<0,05)$. Kadar lemak rempeyek komersial, kontrol, dan formula terbaik dapat dilihat pada Gambar 7.

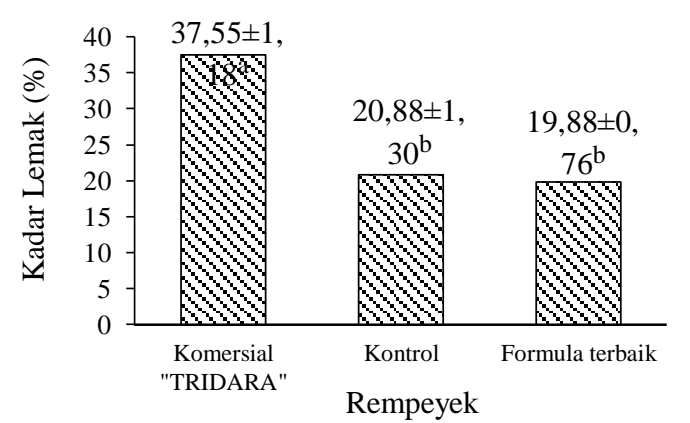

Keterangan: Notasi huruf berbeda menunjukkan adanya perbedaan yang signifikan $(\mathrm{p}<0,05)$

Gambar 7. Kadar lemak rempeyek komersial, kontrol, dan formula terbaik

Gambar 7 menunjukkan substitusi tepung beras hitam dapat menurunkan kadar lemak rempeyek yang dihasilkan. Hal ini terlihat pada kadar lemak rempeyek formula terbaik yang lebih rendah dibandingkan rempeyek kontrol. Penurunan kadar lemak berhubungan dengan peningkatan kadar air rempeyek. Kadar air yang tinggi juga dapat menyebabkan kemampuan produk menyerap minyak semakin tinggi (Nadhiroh \& Susanto, 2017). Hal tersebut dapat terjadi karena ketika air mengguap saat penggorengan, minyak akan menempati rongga yang sebelumnya terisi oleh air (Nadhifah et al., 2016). Kadar lemak rempeyek komersial yang tinggi juga dapat disebabkan rempeyek telah disimpan selama beberapa waktu. Proses penyimpanan dan perbedaan komposisi bahan dalam formula dilaporkan dapat memengaruhi kadar lemak produk lain seperti keripik (Fajriyani, 2019).

\section{Kadar serat pangan rempeyek}

Hasil uji statistik menunjukkan adanya perbedaan yang signifikan untuk kadar serat pangan rempeyek komersial, kontrol, dan formula terbaik $(\mathrm{p}<0,05)$. Kadar serat pangan rempeyek komersial, kontrol, dan formula terbaik ditunjukkan pada Gambar 8. 


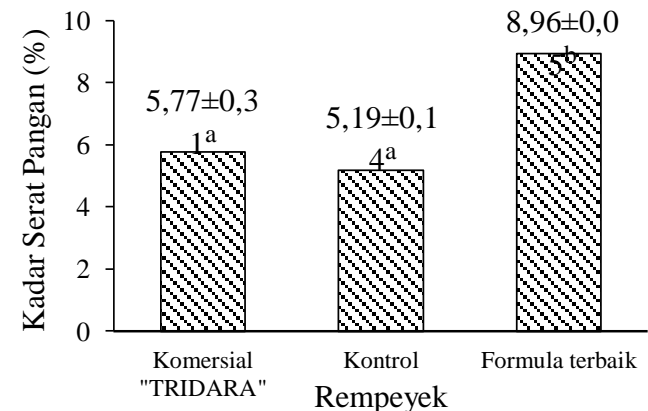

Keterangan: Notasi huruf berbeda menunjukkan adanya perbedaan yang signifikan $(\mathrm{p}<0,05)$

Gambar 8. Kadar serat pangan rempeyek komersial, kontrol, dan formula terbaik

Pada Gambar 8 dapat dilihat rempeyek formula terbaik memiliki kadar serat pangan tertinggi. Hal ini disebabkan kadar serat pangan tepung beras hitam lebih tinggi daripada tepung beras putih. Hasil analisis kadar serat pangan beras hitam organik pada tahap I diketahui sebesar 8,5\%. Tepung beras putih dilaporkan memiliki kadar serat pangan 5,4\% (Hernawan dan Meylani, 2016). Berdasarkan kadar serat pangannya, maka rempeyek formula terbaik dapat digolongkan sebagai pangan tinggi serat. Pangan tinggi serat memiliki kandungan serat pangan minimal 6\% (BPOM, 2016).

\section{Kadar pati resisten rempeyek}

Hasil uji statistik menunjukkan adanya perbedaan signifikan pada kadar pati resisten rempeyek komersial, kontrol, dan formula terbaik $(p<0,05)$. Kadar pati resisten rempeyek komersial, kontrol, dan formula terbaik dapat dilihat pada Gambar 9.

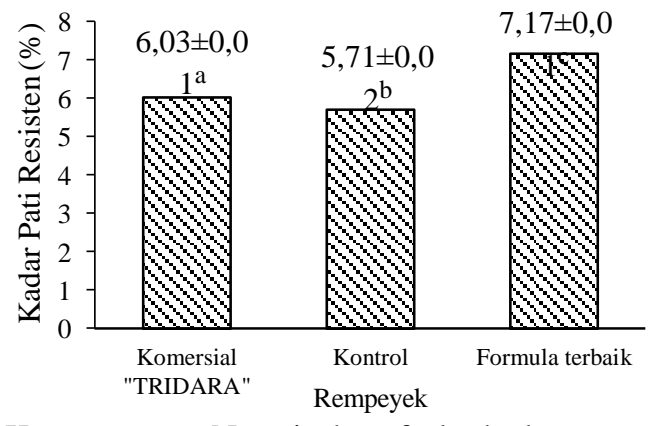

Keterangan: Notasi huruf berbeda menunjukkan adanya perbedaan yang signifikan $(\mathrm{p}<0,05)$

Gambar 9. Kadar pati resisten rempeyek komersial, kontrol, dan formula terbaik
Kadar pati resisten rempeyek tertinggi pada Gambar 9 terdapat pada rempeyek formula terbaik. Hasil analisis kadar pati resisten tepung beras hitam organik pada tahap I diketahui sebesar 3,84\%, sedangkan kadar pati resisten tepung beras putih dilaporkan sebesar 2,15\% (Wakhidana et al., 2018). Adanya substitusi tepung beras hitam mampu meningkatkan kandungan pati resisten rempeyek yang dihasilkan. Kadar amilosa pada beras hitam yang tinggi yaitu sebesar 25,4\% juga dapat menyebabkan kandungan pati resisten rempeyek yang tinggi akibat sifat amilosa yang mampu membentuk struktur kristalin (double helix) yang kompak dan panjang sehingga sulit untuk dicerna (Zhu et al., 2011).

\section{KESIMPULAN}

Beras hitam organik memiliki rendemen $92,63 \pm 0,06 \%$ dengan karakteristik

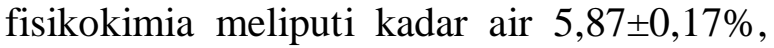
daya serap air $118,07 \pm 3,07 \%$, kadar serat pangan $8,50 \pm 0,15 \%$, dan kadar pati resisten $3,84 \pm 0,01 \%$. Beras hitam non-organik memiliki rendemen $92,55 \pm 0,57 \%$, kadar air $6,32 \pm 0,55 \%$, daya serap air $113,20 \pm 5,48 \%$, kadar serat pangan $7,06 \pm 0,02 \%$, dan kadar pati resisten $1,86 \pm 0,01 \%$.

Semakin tinggi rasio substitusi beras hitam, maka semakin tinggi kekerasan dan daya patah rempeyek yang dihasilkan. Karakteristik fisikokimia rempeyek formula terbaik terdapat pada rasio tepung beras putih dan tepung beras hitam organik 20:80 dengan nilai kekerasan rempeyek 730,28 $\pm 11,74$ gf, daya patah rempeyek $663,87 \pm 5,57$ gf, kadar air rempeyek $2,91 \pm 0,12 \%$, kadar protein rempeyek $6,57 \pm 0,12 \%$, kadar lemak rempeyek $19,88 \pm 0,76 \%$, kadar serat pangan rempeyek 8,96 $\pm 0,05 \%$, dan kadar pati resisten rempeyek $7,17 \pm 0,01 \%$. Secara umum rempeyek formula terbaik memiliki karakteristik fisikokimia yang lebih baik dibandingkan rempeyek komersial. 


\section{DAFTAR PUSTAKA}

Aini, N., Wijanarko, G., \& Sustriawan, B. (2016). Sifat fisik, kimia, dan fungsional tepung jagung yang diproses melalui fermentasi. Agritech, 36(2), 160-169.

https://doi.org/10.22146/agritech.12860

Anugrahati, N. A., Pranoto, Y., Marsono, Y., \& Marseno, D. W. (2015). In vitro digestibility of Indonesian cooked rice treated with cooling reheating process and coconut milk addition. International Research Journal of Biological Science, 4(12), 34-39.

Association of Official Analytical Chemyst (AOAC). (2012). Official methods of analysis of association of official analytical chemist. Virginia: AOAC International.

Badan Pengawas Obat dan Makanan (BPOM). (2016). Peraturan Kepala Badan Pengawas Obat dan Makanan Republik Indonesia Nomor 13 Tahun 2016 tentang pengawasan klaim pada label dan iklan pangan olahan. Jakarta: Badan Pengawas Obat dan Makanan. Retrieved from https://standarpangan.pom.go.id/dokum en/peraturan/2016/PerKa_BPOM_No_ 13_Tahun_2016_tentang_Klaim_pada_ Label_dan_Iklan_Pangan_Olahan.pdf

Engelen, A. (2018). Analisis kekerasan, kadar air, warna dan sifat sensori pada pembuatan keripik daun kelor. Journal of Agritech Science, 2(1), 10-15. https://doi.org/10.30869/jasc.v2i1.173

Fajriyani, A., Hersoelistyorini, W., \& Nurhidajah. (2019). Nilai TBA, FFA, kadar air dan sifat sensori keripik kentang berdasarkan jenis kemasan dan lama penyimpanan. Jurnal Pangan dan Gizi, 9(2), 54-68. https://doi.org/10.26714/jpg.9.2.2019.5 4-68

Hernawan, E. \& Meylani, V. (2016). Analisis karakteristik fisikokimia beras putih, beras merah, dan beras hitam (Oryza sativa L., Oryza nivara dan Oryza sativa L. indica). Jurnal Kesehatan
Bakti Tunas Husada, 15(1), 79-91. http://dx.doi.org/10.36465/jkbth.v15i1. 154

Hidayat, R. R., Sugitha. I. M., \& Wiadnyani, A. A. I. S. (2019). Pengaruh perbandingan tepung beras hitam (Oryza sativa L. indica) dengan terigu terhadap karakteristik bakpao. Jurnal Ilmu dan Teknologi Pangan, 8(2), 207215. https://doi.org/10.24843/itepa.2019.v08 .i02.p11

Jagat, A. N., Pramono, Y. B., \& Nurwantoro. (2017). Pengkayaan serat pada pembuatan biskuit dengan substitusi tepung ubi jalar kuning (Ipomea batatas L.). Jurnal Aplikasi Teknologi Pangan, 6(2), 1-4. http://dx.doi.org/10.17728/jatp.190

Kahono, G. A., Rahmawati, D., Prawira, I. K. P. Y., Puteri, M. D. P. T. G., \& Marpaung, A. M. (2018). Preferences and factors influencing the purchase intention of healthy snacks among millennials in Jakarta. International Conference on Food, Agriculture and Biotechnology. Thailand: ICoFAB.

Kakar, K., Nitta, Y., Asagi, N., Komatsuzaki, M., Shiotsu, F., Kokubo, T., \& Xuan, T. D. (2019). Morphological analysis on comparison of organic and chemical fertilizer on grain quality of rice at different planting densities. Plant Production Science, 22(4), 510-518. https://doi.org/10.1080/1343943X.2019 .1657777

Kopittke, P. M., Menzies N. W., Wang, P., McKenna, B. A., \& Lombi, E. (2019). Soil and the intensification of agriculture for global food security. Environment International, 132:1-8. https://doi.org/10.1016/j.envint.2019.1 05078

Kristamtini, Taryono, Basunanda, P., \& Murti, R. H. (2014). Keragaman genetik dan korelasi parameter warna beras dan kandungan antosianin total sebelas kultivar padi beras hitam lokal. Ilmu Pertanian, 17(1), 57-70. 
Maureen, B., Surjoseputro, S., \& Epriliati, I. (2016). Pengaruh proporsi tapioka dan tepung beras merah terhadap sifat fisikokimia dan organoleptik kerupuk beras merah. Jurnal Teknologi Pangan dan Gizi, 15(1), 43-52. https://doi.org/10.33508/jtpg.v15i1.153 1

Mustafa, A. (2015). Analisis proses pembuatan pati ubi kayu (tapioka) berbasis neraca massa. Jurnal Agrointek, 9(2),127-133. https://doi.org/10.21107/agrointek.v9i2 .2143

Nadhiroh, U. \& Susanto, W. H. (2017). Pengaruh volume minyak goreng dan bentuk biji edamame (Glycine max Linn. Merill) terhadap karakteristik produk edamame goreng metode penggorengan vakum. Jurnal Pangan dan Agroindustri, 5(1), 26-37.

Nadhifah, M., Diniyah, N., Windrati, W. S., \& Subagio, A. (2016). Sifat fisik, kimia, organoleptik rempeyek berbahan mocaf (modified cassava flour). Prosiding Seminar Nasional APTA. Jember: TIP Universitas Jember.

Ntau, L., Sumual, M. F., \& Assa, J. R. (2017). Pengaruh fermentasi Lactobacillus casei terhadap sifat fisik tepung jagung manis (Zea mays saccharate Sturt). Jurnal Ilmu dan Teknologi Pangan, 5(2), 11-19.

Nurhidajah, Ulvie, Y. N., \& Suyanto, A. (2018). Karakteristik fisik dan kimia beras hitam dengan variasi metode pengolahan. Prosiding Seminar Nasional Unimus 1:216-221. Semarang: Universitas Muhammadiyah.

Paramida, N. R., Karo-Karo, T., \& Yusraini, E. (2013). Studi pembuatan rempeyek bercitarasa daun kayu manis. Jurnal Rekayasa Pangan dan Pertanian, 1(4), 39-46.

Purnama, R. C., Winahyu, D. A., \& Sari, D. S. (2019). Analisis kadar protein pada tepung kulit pisang kepok (Musa acuminate balbisiana colla) dengan metode Kjeldahl. Jurnal Analisis Farmasi, 4(2), 77-83.

Rauf, R. \& Sarbini, D. (2015). Daya serap air sebagai acuan untuk menentukan volume air dalam pembuatan adonan roti dari campuran tepung terigu dan tepung singkong. AGRITECH, 35(3), 324-330. https://doi.org/10.22146/agritech.9344

Rozali, Z, F., Purwani, E. Y., Iskandriati, D., Palupi, N. S., \& Suhartono, M. T. (2018). Potensi pati resisten beras sebagai bahan pangan inovatif. Jurnal Pangan, 27(3), 215-224.

Saleh, A. S. M., Wang, P., Wang, N., Yang, L., \& Xiao, Z. (2019). Brown rice versus white rice: Nutritional quality, potential health benefits, development of food products, and preservation technologies. Comprehensive Reviews in Food Science and Food Safety, 18, 1070-1096.

https://doi.org/10.1111/15414337.12449

Sari, A. R., Martono, Y., \& Rondonuwu, F. S. (2020). Identifikasi kualitas beras putih (Oryza sativa L.) berdasarkan kandungan amilosa dan amilopektin di pasar tradisional dan "Selepan" Kota Salatiga. Jurnal Ilmiah Multi Sciences, 12(1):24-30.

https://doi.org/10.30599/jti.v12i1.599

Sugiyono, Mariyana, E., \& Yulianto, E. (2013). Pembuatan crackers jagung dan pendugaan umur simpannya dengan pendekatan kadar air kritis. Jurnal Teknologi dan Industri Pangan, 24(2),

129-137. https://doi.org/10.6066/jtip.2013.24.2.1 29

Sulistyana, P., Mulyo, J. H., \& Jamhari. (2014). Konsumsi beras organik pada tingkat rumah tangga di Kota Yogyakarta. Agro Ekonomi, 24(1), 2534.

https://doi.org/10.22146/agroekonomi. 17357

Sundari, D., Almasyhuri, \& Lamid, A. (2015). Pengaruh proses pemasakan terhadap komponen zat gizi bahan 
pangan sumber protein. Media Litbang, 25(4),

http://dx.doi.org/10.22435/mpk.v25i4.4 590.235-242

Vigar, V., Myers, S., Oliver, C., Arellano, J., Robinson, S., \& Leifert, C. (2020). A systematic review of organic versus conventional food consumption: Is there a measurable benefit on human health? Nutrients, 12(1), 1-7. https://doi.org/10.3390/nu12010007

Wakhidana, G. A., Marchianti, A. C. N., \& Santosa, A. (2018). Uji efektivitas beras herbal forte terhadap penurunan kadar glukosa darah pasien diabetes melitus tipe 2. e-Jurnal Pustaka Kesehatan, 6(1), 85-91. https://doi.org/10.19184/pk.v6i1.6789

Wulandari, F., K., Setiani, B., E., \& Susanti, S. (2016). Analisis kandungan gizi, nilai energi, dan uji organoleptik cookies tepung beras dengan substitusi tepung sukun. Jurnal Aplikasi Teknologi Pangan, 5(4), 107-112. http://dx.doi.org/10.17728/jatp.183

Zhu, L. J., Liu, Q. Q., Wilson, J. D., Gu, M. H., \& Shi, Y. C. (2011). Digestibility and physicochemical properties of rice (Oryza sativa L.) flours and starch differing in amylose content. Carbohydrate Polymers, 86, 17511759.

https://doi.org/10.1016/j.carbpol.2011. 07.017 